\title{
Make hay while the sun shines
}

$\mathrm{S}$ he and I had endured what seemed like an excruciating, unnecessarily long period of diagnostic frustration, awaiting some answers - any answers - to what was plaguing her. Brief lapses in recent memory. Losing her keys - shoot, I'd done that myself more than once. Mild disorganization, leaving bedroom and bathroom lights on - me too - but this was way out of character for the highly organized woman I had known and loved for more than 12 years.

Now the results of her visit to the neuropsychologist had been relayed to her neurologist who in turn would pass on the stinging news to us.

"It's TIAs, isn't it?" the anxious physician within me asked hopefully.

The doctor shook his head slowly, quietly but surely. Then he explained that my wife had Alzheimer disease or, as he then diplomatically shortened it, "AD." She has early onset Alzheimer disease, first symptomatic when she was only 62 , an age when very few in the general population are so unfairly stricken.

Before we left his office, he wrote her a prescription for memantine, one of the 4 or 5 medicines that help slow, but not stop the progress of this relentlessly cruel and pitiless memory-killer. As we drove back to our home on Vancouver's north shore, she began crying quietly. "Do you want to share?" I asked at a stoplight.

"Well... you've been through this before!" she observed, referring to the death of my first wife.

"Well... so have you, honey!" I said, reminding her that she too had lost a partner, her first husband to pancre$\vec{\infty}$ atic cancer. We were mostly quiet as we drove the rest of the way home, our private, probably overlapping thoughts, fears and fantasies swirling in our respective heads.

Later I silently mused over the recent stories in the media reporting the chal-

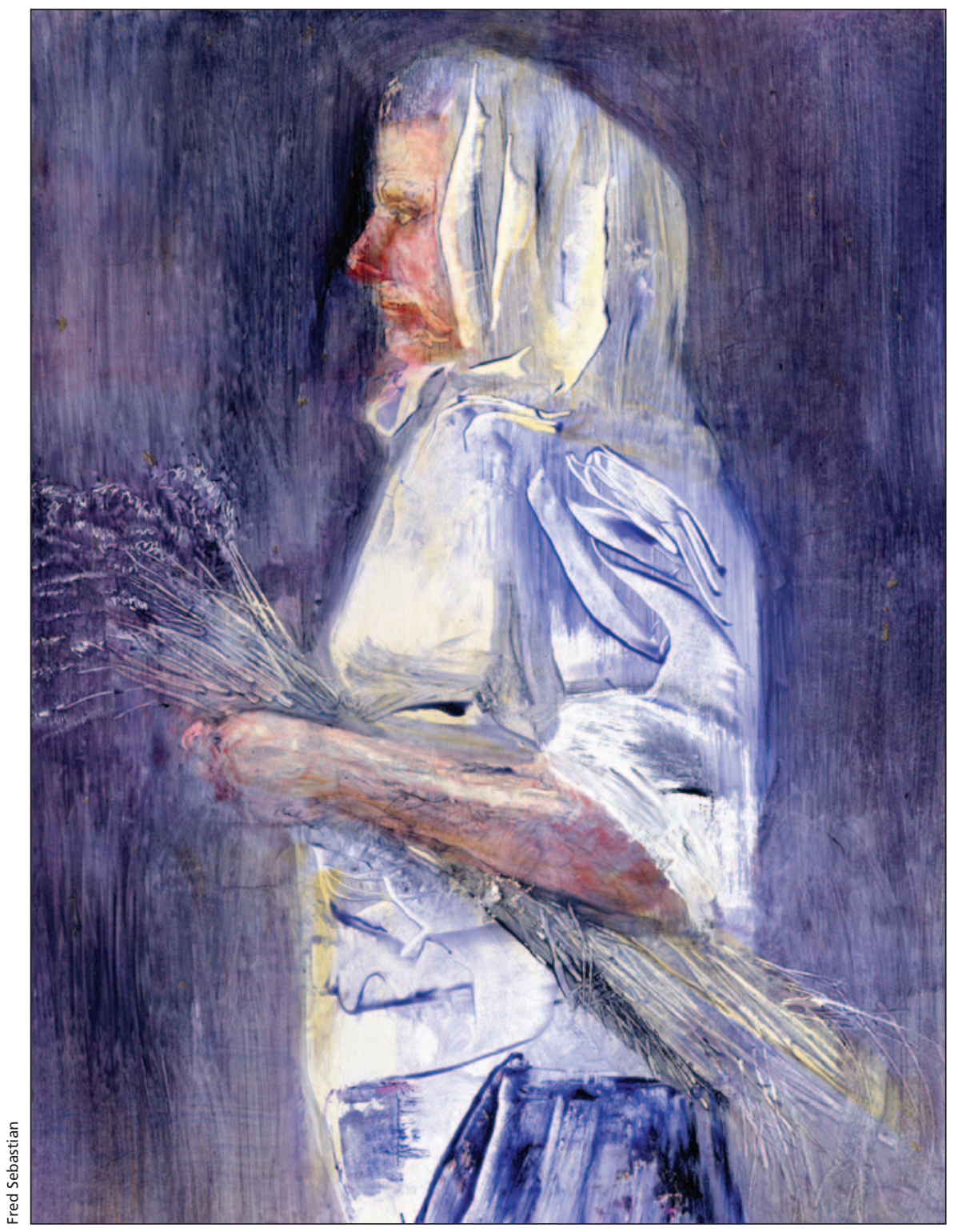

lenges faced by the many families living with someone suffering from Alzheimer disease. But most of these focused on the difficulties facing individuals looking after parents struggling with this progressive dementia. Only a very few acknowledged the trials experienced by husbands and wives now caring for their similarly afflicted spouses, some at home, some in nursing homes and some probably during periods of change that are difficult for both partners even in the absence of illness. My wife insisted we see the movie Away from Her, starring Julie Christie and Gordon Pinsent, that highlights this time of transition. We laughed. We cried. Afterward we shared our feelings softly while savouring East Indian food.

Today she is at home with me, and 
me with her; we both hope it stays that way for a long, long time. There are many challenges however, and also opportunities in this newest phase of our marriage and personal lives. A gifted, tough-minded, but warm psychologist overseeing 4 mental health clinics in British Columbia, she has been forced to shut down her own clinical practice. A large part of her identity centred around her work, with the many clients that she has helped over the years and the associated rewards of appreciation from those she has helped, and of knowing that she has provided quality psychotherapy and that at the end of the day she has indeed made a difference.
As for me, I have learned that I can make 2 types of mistakes in our daily to-and-fro and give-and-take. The first kind is the anxious husband reaching out to help his wife when she neither needs nor wants assistance. The second type of error sees me missing an opportunity to help her when she genuinely needs it. Type 1 errors are more common and really tee her off. Type 2 errors are mercifully less frequent, or so she says.

I comfort her when she's having a bad day, feeling irritated or frustrated. And sometimes I feel cheered up myself, reassured and relieved in being able to be there for her. Most days we enjoy each other and, sometimes, hugely. Laughing. Fight- ing. Making up. Making love. Teasing and joking. Snuggling. Tasting her superb rhubarb crisp. So just as in the time before Alzheimer disease came into our lives, on our very best days we live contentedly in the moment, in the here-and-now.

After all, isn't that what any of us would do on a good day when we're with those who count - our family and friends? Alzheimer disease is just an unkind, uninvited stranger in our midst. But we don't have to wait until it comes rudely visiting before we enjoy our wife or husband or partner, other family or friends, before we appreciate — and acknowledge — how much they mean to us.

My grandmother said it better than ever I could have. "Make hay while the sun shines!" she would remind me today.

\section{David Kirkpatrick MA MD}

Psychiatrist and psychotherapist West Vancouver, BC

\section{Past progressive}

\section{The glorification of gout in 16th- to 18th-century literature}

$\mathrm{L}$ iterary references to gout are a prime example of the insight into popular perceptions of disease that historical writings offer. While praise of podagra is currently in short supply, the merits of gout have been extolled over the centuries by physicians and laypersons. In the past, gout was regarded as a badge of nobility, a talisman against other afflictions and an aphrodisiac, and these beliefs were preserved in 16th- to 18 th-century literature.

\section{A mark of nobility}

Gout as a disease of the nobility was referred to and explained in a popular fable involving Mr. Gout and the spider. This story has been traced to the ninth century, ${ }^{1}$ and the first English version of it was recorded in a medical handbook by the Puritan Richard Hawes in $1634 .^{2}$
The tale tells of Monsieur Gout and his travelling companion, the spider. Mr. Gout lodged with a poor man, and the spider with a rich man. When they reviewed their accommodations the next day, both had complaints.

“"Mine,' said the Gout, 'was the worst as ever I had, for I had no sooner touched the poor man's legs, thinking there to take my rest, but up he gets, and to thrashing he goes, so that I had no rest the whole night.'

'And I,' said the spider, 'had no sooner begun to build my house in the rich man's chamber, but the maid came with a broom, and tore down all my work." ${ }^{3}$

They then agreed to change places and were so pleased with their respective new homes that they each decided to put up permanent residence, for the spider's webs were not disturbed by the poor man, and "the Gout he was enter- tained with a soft cushion, with down pillows, with dainty caudles, and delicate broths. In brief, he did like it so well, that ever since he takes up his lodging with rich men." ${ }^{3}$

This fable purports to explain gout's apparent predilection for the upper class. Gout was referred to as morbus dominorum et dominus morborum, lord of disease and disease of lords,,${ }^{4,5}$ because of its respectable antiquity and its association with intemperance afforded only by the wealthy. Gout was personified as one of the Greek deities, Podagra, born of Dionysus (Bacchus), the god of wine, and Aphrodite (Venus), the goddess of love. ${ }^{5-7}$ The idea that gout resulted from service to these gods and was a consequence of overindulgence in sex, food and wine was recorded by ancient Roman authors and persisted into the Christian era. ${ }^{6-8}$ 